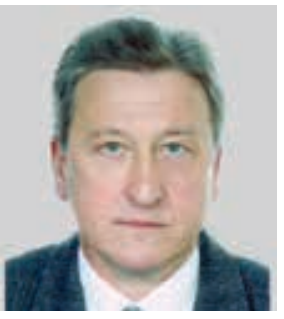

Геннадий Петрович ТОЛСТОПЯТЕНКО decanatmp@mgimo.ru 119454, Россия, г. Москва, просп. Вернадского, д. 76

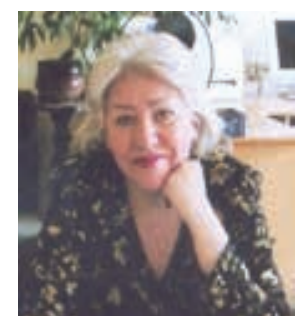

Ирина Григорьевна ФЕДОТОВА

karavaeva63@yandex.ru 119454, Россия, г. Москва, просп. Вернадского, д. 76

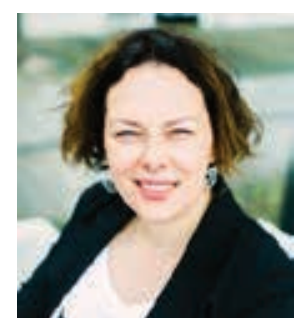

Ирина Анатольевна БОГДАНОВА irina.a.bogdanova@ gmail.com

119454, Россия, г. Москва, просп. Вернадского, д. 76

(ㄷ.Г.П. Толстопятенко, И. Г. Федотова, И. А. Богданова, 2020

\section{АНГЛИЙСКИЙ ЯЗЫК. НАУЧНАЯ ШКОЛА ЛИНГВОПРАВОВЕДЕНИЯ МЕЖДУНАРОДНО-ПРАВОВОГО ФАКУЛЬТЕТА МГИМО}

Аннотация. Статья посвящена особенностям языковой подготовки юристов-международников. Авторы описывают подход, сложившийся в рамках научной школы лингвоправоведения международно-правового фракультета МГИМО (У) МИД России и доказавший свою эффрективность при обучении языку специальности. В рамках данного подхода лингвистика и правоведение становятся равнозначными и равноправными составляющими в получении целостной картины изучаемого объекта - системы юридических понятий и категорий страны изучаемого языка, что полностью соответствует дидактическим целям, преследуемым при подготовке юристов-международников специалистов, которые должны не просто оперировать иноязычными терминами, но, понимая стоящие за ними внеязыковые реалии, обеспечивать подлинный диалог культур, жизненно необходимый в условиях современного общества.

Ключевые слова: юридический английский, преподавание английского языка юристам-международникам, школа лингвоправоведения, подготовка юристов-международников, юридические понятия и категории в английском языке, англо-американская правовая система.

DOI: $10.17803 / 2311-5998.2020 .65 .1 .062-069$ 


\begin{tabular}{|c|c|}
\hline П & $\begin{array}{l}\text { Толстопятенко Г. П., Федотова И. Г., Богданова И. А. } \\
\text { Английский язык. Научная Школа лингвоправоведения } \\
\text { международно-правового факультета МГИМ口 }\end{array}$ \\
\hline
\end{tabular}

\title{
G. P. TOLSTOPYATENKO,
}

International Law Faculty Dean MGIMO-University, L.D., Professor

decanatmp@mgimo.ru

119454, Russia, Moscow, prosp. Vernadskogo, 76

I. G. FEDOTOVA, Head of English Department No. 8, International Law Faculty, MGIMO-University, Associate Professor karavaeva63@yandex.ru 119454, Russia, Moscow, prosp. Vernadskogo, 76

I. A. BOGDANOVA, Associate Professor of English Department No. 8, International Law Faculty, MGIMO-University, Ph.D in Philology

irina.a.bogdanova@gmail.com

119454, Russia, Moscow, prosp. Vernadskogo, 76

\section{STUDY OF LAW THROUGH LANGUAGE APPROACH AS ADOPTED IN TEACHING INTERNATIONAL LAWYERS AT MGIMO-UNIVERSITY}

\begin{abstract}
The article focuses on teaching English to international lawyers. The authors describe the approach developed and adopted in teaching legal English to international lawyers at MGIMO-University. Within the framework of this approach linguistics and jurisprudence become equivalent and equal factors in building a concise picture of the target subject - the system of the legal concepts and legal terminology of a foreign language. In the opinion of the authors this should be viewed as an important didactic goal of international lawyer training, i.e. training a professional who is not only able to fluently use foreign terminology, but, having thoroughly understood the respective extra lingual realia, contribute to a true dialogue of cultures vital to modern social interaction. Keywords: legal English, legalese, teaching legal English, teaching legal English to international law students, the Anglo-American legal concepts and legal terminology, Anglo-American legal system.
\end{abstract}

T he process of training an international lawyer can be characterized by certain specific features. Firstly, the study of comparative jurisprudence implies professional level of fluency in foreign languages. Nowadays fluency in English, in particular in the sphere of law, has become essential to professional success. From this viewpoint the development of the skill and ability to adequately grasp the gist and detail of a legal text, make a speech and/or discuss a professional topic in English, as well as translate and/or interpret from English into Russian and vice versa, should be viewed as one of the main goals of training an international lawyer.

Thus, in the course of training special attention should be paid to the study of the Anglo-Saxon (Anglo-American) system of law. 
Among the foremost achievements of Anglophone culture one of the top places should undoubtedly be given to the Anglo-Saxon system of law.

Having avoided the Roman law influence and taking a firm stand on the foundation of judicial practice instead of formal regulatory wording, the Anglo-Saxon system of law allotted the top priority to the Precedent, having digested both the historic experience of England and the endless variety of actual diversities among its natives, as well as the age-old wisdom of generations seeking an answer to the eternal question of what is just or unjust as opposed to the dead scholasticism of statutory law.

The content, however, needs a form. And a more ideal fusion of form and content than the English language and the Anglo-Saxon system of law is hard to imagine. The English language with its opulent vocabulary, harmonious grammar, semantic accuracy and stylistic flexibility played an important part in the shaping of the AngloSaxon system of law as its natural "melting pot", inevitably eliminating the borders between the extra textual and properly linguistic factors forming a single environment extremely beneficial to democratic social development.

Thus, the Anglo-American system of law has, in the course of its centuries-old growth, developed a clear and harmonious sublanguage of law structure setting forth a strict correlation between a legal realia and the term describing it.

That is why with reference to law the well-known saying: "A word is the skin of a living thought" means that at all times the wording of statutes and judgments has reflected the state of legal thought representative of a particular epoch.

In this respect the study of the legal concepts and legal terminology system of a target language shall unavoidably embrace two aspects: the terminology describing legal realia and linguistic analysis of a legal text.

The first aspect is an essential part of lingvo-jurisprudence that, in its turn, is part of lingvo-geography in the meaning of culture-through-language studies aimed at learning a foreign language based on the analysis of cultural realia descriptions, including legally oriented materials, by linguistic methods.

The second aspect is closely related to juridical linguistics aimed at linguistic analysis of a legal text with a view to its lingvo-cognitive, lingvo-communicative and lingvo-psychological interpretation.

Consolidation of the two aforementioned aspects shall signify the synergic approach turning linguistics and jurisprudence into equivalent and equal factors in building a concise picture of the target subject - the system of the legal concepts and legal terminology of a foreign language. In our opinion this should be viewed as an important didactic goal of international lawyer training, i.e. training a professional who is not only able to fluently use foreign terminology, but, having thoroughly understood the respective extra lingual realia, contribute to a true dialogue of cultures vital to modern social interaction.

\section{Aims and Targets of Academic Course}

The general aim of the course "Legal Concepts and Legal Terminology in English. Translation and Interpreting Skills" is to train a student to carry out professional functions in English in the field of law. 


\begin{tabular}{|c|c|}
\hline 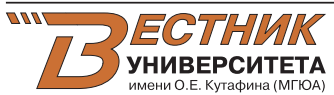 & $\begin{array}{l}\text { Толстопятенко Г. П., Федотова И. Г., Богданова И. А. } \\
\text { Английский язык. Научная Школа лингвоправоведения } \\
\text { международно-правового факультета МГИМО }\end{array}$ \\
\hline
\end{tabular}

In order to achieve this aim one is to reach the following targets:

\section{Study of Special Legal Terminology}

The study of the lexico-grammatical characteristics, as well as the structural and semantic features of an English term and its interpretation in Russian.

In this respect one is to consider the source and the lexical background of the respective terminology, discrepancy between the British and American Terms describing a particular concept and the cause of the same; the principles of interpreting an English term by means of the Russian language subject to the structural and semantic divergence of the two languages.

Gradual acquisition of terminology thesaurus covering every target Anglo-American law institution or branch.

Legal perfection is based on precise comprehension. In judicial practice precise comprehension is a guarantee of a fair resolution of issues of fact and accurate interpretation of law issues. Thus, nowadays an adequate application of written and/or oral language is one of the most important means of conflict resolution. Every language is based on vocabulary. It is the word that reflects and describes the respective realia. The more perfect is the conception of such a realia, the more accurate shall be the respective verbal description. The age-long development of the Anglo-Saxon system of law and its sublanguage has resulted in a harmonious correlation between the realia of law and the respective terms. As an essential part of the English language the legal terminology has naturally grown and developed within its structure. Moreover, being in fact common words used in a special meaning, legal terms have never been treated as something alien. They have always been an inherent part of the living language structure ensuring precise comprehension - the criterion of perfection in law.

\section{Comprehension of Lexico-grammatical Characteristics of Legal Texts}

There is no doubt that translation/interpretation is one of the most complicated types of activity. In order to transfer information from one semiotic system into another in the absence of conceptual equivalence between realia belonging to various national cultures, the translator/interpreter should not just be perfectly fluent both in the source and the target language but also have an outstanding analytical ability, as well as extensive professional and background knowledge accompanied by the skill of exercising several functions simultaneously, as a result ensuring perfectly adequate comprehension of the underlying content by the parties to interlingual communication.

In English like in many other so called analytically structured languages, along with the word order a great role is allotted to auxiliary words. Quite a few of them are homonymous and subject to their function may have a different meaning, and consequently require a different translation/interpretation.

Moreover, in English there are certain syntactic structures quite frequently used in legal texts and posing a problem due to a difficulty of choosing an adequate Russian equivalent and even the necessity of transforming the whole sentence structure.

\section{Developing Translation and Interpreting Skills}

The criterion of quality for any translation is the level of its equivalency with the original. However, even keen on the maximum equivalency the translator should avoid two extremes: literalism (the so called "word for word translation") on the one hand, and arbitrariness ("loose translation") on the other, since translation is neither a mechanic conversion of information from one semiotic system into another, nor 
an independent creation more or less similar to the original. Translation is an act of interlingual communication including both a linguistic form and a linguistic interpretation of a communicative event, as well as a wide variety of extra lingual factors dependent on the general and national cultural peculiarities.

Sometimes the original text needs no extensive lexical or grammatical transformation and the equivalents may practically be picked automatically. However, translation of a more complicated text shall be a more difficult job calling for a substantive correlation of the original and the target language structures in order to select optimal transformation models to transfer information from one language to another. Then translation will resemble a creative process somewhat akin to a writer's.

Finally, it should be mentioned that translation as a type of activity in any domain, in this case jurisprudence, concerned with dissimilar law systems implies:

a) fluency in both the original and the target language;

b) professional mastery of special legal terminology;

c) adequate knowledge of comparative jurisprudence.

Besides, in spite of a translator's having to perform several operations simultaneously, the translation process clearly includes the following aspects reflecting the mechanics of such a text translation:

General professional and semantic text analysis in order to determine its topical attributes at the pre-translation stage.

Picking out the basic key terminology reflecting the informative gist of the text to be translated.

Conceptual and notional analysis of the selected terms in order to determine the difference between the similar terms belonging to dissimilar legal systems (Russian and Anglo-American).

Notion communication through explanation instead of direct translation due to the absence of conceptual equivalence between the terms used in the two dissimilar legal systems.

Analysis of the lexico-grammatical and syntactic demons in the text.

The text final edit in order to adjust its rhythm and style.

Another skill trained within the academic course is Interpretation, where a professionally-oriented text is to be perceived from an audio-recording (an auxiliary type of interpretation) or is read by the instructor (consecutive two-way interpretation).

The following skills and abilities are to be trained in the course of consecutive interpretation:

The skill of conceptual text analysis while actually listening to the text, i.e. the ability to transform the text to subsequently reproduce it in another language;

The ability to make simultaneous notes of the thus transformed text, i.e. to use mental notes in the course of interpreting of a comparatively long remark of the speaker;

The ability to stay within the time limits set forth by the rhythm of the conversation (business meeting, interview, etc.) relying on fast response, quick switch from one language to another and a well-trained short-term memory;

The ability to use background knowledge extended through systemic and regular multi-topical dialogue interpretation and continuous terminological vocabulary build-up. 


\begin{tabular}{|c|c|}
\hline 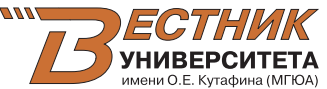 & $\begin{array}{l}\text { Толстопятенко Г. П., Федотова И. Г., Богданова И. А. } \\
\text { АнГЛИйскИй яЗьК. НауЧная школа ЛИНГвоправоведения } \\
\text { Международно-Правового факультета МГИМО }\end{array}$ \\
\hline
\end{tabular}

\section{Informative Aspect}

The course is based on the academic complex by I. G. Fedotova and G. P. Tolstopyatenko "Legal Concepts and Legal Terminology in English", initially published in 1998 and repeatedly republished ever since. At present it includes the following componentry:

1) I. G. Fedotova, G. P. Tolstopyatenko "Legal Concepts and Legal Terminology in English" (school book) (Statute Publishers, 2014);

2) I. G. Fedotova, G. P. Tolstopyatenko "Legal Concepts and Legal Terminology in English" (glossary) (Statute Publishers, 2014);

3) I. G. Fedotova, G. P. Tolstopyatenko, N. V. Staroselskaya, N. A. Ishevskaya "Tutorial in Legal Translation from English into Russian and Vice Versa" (school book) (Statute Publishers, 2017).

The school book "Legal Concepts and Legal Terminology in English" and the glossary included in the complex introduce a student to the basics of the public international law and the Anglo-American law system.

Thereon, a more detailed penetration into the particulars of the Anglo-American law system is carried out on the base of a two-fold teaching aid by I. G. Fedotova, N. V. Staroselskaya and G. P. Tolstopyatenko "The Anglo-American Legal Concepts and Legal Terminology" (MGIMO-University Press, 2017).

It is the latter that lays the foundation for tuition in written-written and written-oral translation.

The academic course includes extensive use of the UN library public international law video lectures and audio lectures recorded by the US leading professors of law for the students of the US universities' law schools. The lectures cover all the various aspects of the legal subjects on the curriculum and lay a foundation for teaching the skill of oral-oral interpretation with the help of video and audio recordings, lecture transcripts, as well as the tutorial by N. V. Staroselskaya for instruction on listening to legal materials for the International Law Faculty students.

As an essential part of the academic course, its extensive reference materials include:

Legal thesauri, published in the USA or Great Britain;

Charts giving the gist of every branch of law on the curriculum in the form of "Bar Charts" or "The essential university course outline", devised for American Law School students;

Original legal document blanks.

Teaching the language for special purposes implies development of skills and abilities in each of the four types of language activity: reading, writing, listening and speaking.

Development of translation/interpreting skills is based on the theory of translation devised by L. S. Barkhudarov, V. N. Komissarov, Y. I. Retsker. At the same time translation is an auxiliary means to development of a consistent fluent professional legal literature reading skill.

As above noted, interpretation is also a means of training listening skills.

Legal writing skills are built through writing background reports on a given topic or devising a legal instrument (memorandum of law, case brief, opinion or client letter). 
Oral professional skills are built in the course of preparing reports on the law areas covered, or a student's participation in a case study. Further development of oral skills takes place in the course of studying for a master's degree. It is this academic stage with its mature level of both language and professional competence that is deemed to be optimal for participation in simulation games based on case study.

It should be mentioned that since a Law Faculty MGIMO graduate may also be required to translate from Russian into English, a prominent place in the second year master's training is devoted to the Russian-English translation course, including both the theoretical guidelines and principles, and tutorials in Russian-English translation with special attention paid to original business documentation of the Russian law firms and companies collaborating with foreign partners.

Thus, the professionally-oriented aspect is in fact aimed at a two-fold goal: provides a student with a clear and immediate understanding of the Anglo-American legal concepts and terminology opening to him/her a unique future opportunity of performing professional functions in English within the framework of the Anglo-American system of law, on the one hand, and an optimal ability of working within our national law system in furtherance of cooperation and mutual understanding of co-professionals speaking and thinking in different languages.

\section{International Law Faculty Lingvo-jurisprudence School Background}

Today we can state that the International Law Faculty has given rise to a unique school of teaching language for special purposes. Obviously, it has grown by stages with the experience acquired serving as an opportunity to adjust the aims and targets of tuition, and, consequently, the manner and technique of international lawyer training.

Initially the professional aspect instruction technique copied the general language tuition methods differing only by the choice of material. In the former case it was legallyoriented material - generally the UN documents.

Thereon came the understanding of insufficiency of such an approach as to training a professional fit to act successfully in English that, in its turn, led to a necessity of choosing a different sort of materials and another approach to training an international lawyer. The new approach was initiated by Associate Professor V. F. Nazarov with his "Course in Legal Translation on Anglo-American Commercial Law" published in 1994 and summing up the teaching experience of the legal translation unit in 1972-1994. The present stage starting in 1994 has brought the legal aspect to a new level marked by the academic complex "Legal Concepts and Legal Terminology in English" by I. G. Fedotova and G. P. Tolstopyatenko giving rise to a new approach to training a professional international lawyer.

Nowadays, as a result of innovation technique rapid development the academic basis of the school of lingvo-jurisprudence has been replenished by a new training technique based on a multimedia "Legal English Course". 


\section{REFERENCES}

1. Fedotova I. G., Staroselskaya N. V., Tolstopyatenko G. P. The Anglo-American Legal Concepts and Legal Terminology. — Part I. — M. : MGIMO-University Press, 2017.

2. Fedotova I. G., Staroselskaya N. V., Tolstopyatenko G. P. The Anglo-American Legal Concepts and Legal Terminology. — Part II. — M. : MGIMO-University Press, 2019.

3. Fedotova I. G., Tolstopyatenko G. P. Legal Concepts and Legal Terminology in English (school book). - M. : Statute Publishers, 2014.

4. Fedotova I. G., Tolstopyatenko G. P. Legal Concepts and Legal Terminology in English (glossary). - M. : Statute Publishers, 2014.

5. Fedotova I. G., Tolstopyatenko G. P., Staroselskaya N. V., Bogdanova I. A. Online Multimedia Course "Legal English". — 2019.

6. Fedotova I. G., Tolstopyatenko G. P., Staroselskaya N. V., Ishevskaya N. A. Tutorial in Legal Translation from English into Russian and Vice Versa (school book). M. : Statute Publishers, 2017.

7. Staroselskaya N. V. Listening and Interpreting Skills Manual (to Audio Lectures on Anglo-American Law). — M. : MGIMO-University Press, 2019. 